\title{
Renewable Energy Technologies for Economic Development
}

\author{
Kamaruddin Abdullah ${ }^{1 *}$, Aep Saepul Uyun ${ }^{1}$, Rahedi Soegeng ${ }^{1}$, Eri Suherman ${ }^{1}$, \\ Herry Susanto ${ }^{1,2}$, Roy Hendroko Setyobudi ${ }^{1,3}$, Juris Burlakovs ${ }^{4}$, and Zane Vincēviča-Gaile ${ }^{5}$ \\ ${ }^{1}$ Graduate School of Renewable Energy, Darma Persada University, \\ Jl. Taman Malaka Selatan No.22, Jakarta Timur, 13450, Indonesia \\ ${ }^{2}$ Department of Mechanical Engineering, Darma Persada University, \\ J1. Taman Malaka Selatan No.22, Jakarta Timur, 13450, Indonesia \\ ${ }^{3}$ Department of Agriculture Science, Postgraduate Program, University of Muhammadiyah Malang, \\ Jl. Raya Tlogomas No.246, Malang, 65145, Indonesia \\ ${ }^{4}$ Department of Water Management, Estonian University of Life Sciences, \\ Friedrich Reinhold Kreutzwaldi la 51014 Tartu, Estonia \\ ${ }^{5}$ Department of Environmental Science, University of Latvia, \\ Jelgavas Street 1, Room 302, Riga LV-1004, Latvia
}

\begin{abstract}
Indonesian villages are facing dangerous condition. Every year, young people are deserting the villages. To overcome this problem, Tangsi Jaya hamlet, West Java, has been provided with $18 \mathrm{~kW}$ micro-hydro to supply electricity both to the community and to Small Processing Center for ground coffee production. Results of cash flow analysis for ground coffee in Tangsi Jaya hamlet, with total investment of IDR 110750000 and discount rate of $18 \%$ for 5 yr. Banyumeneng I hamlet, Yogyakarta with an investment cost IDR 95000000 and production cost of IDR $34195000 \mathrm{yr}^{-1}$ and the interest rate of $14 \% \mathrm{yr}^{-1}$, the payback period was estimated to be $3 \mathrm{yr}$ with ROI of $40 \%$. PEST analysics indicate that the higher electricity tariff and interest rate while the higher the value of technology and number of people involve with the SPC will result in the bigger value of ROI. Renewable energy technology could be used for value added activities in rural areas, create small industries, provide job opportunities to the local people and create conditions for sustainable economic development. However, vigilance is needed because small industries can also cause pollution because they produce waste
\end{abstract}

Key words: Clean energy, increase economic sector in rural area, small processing center, waste utilization, zero waste

\section{Introduction}

Indonesian villages face dangerous conditions if corrective action cannot be taken immediately. Every year, regardless of the potential resources in the countryside, young men and women leave the village in search of a better life in big cities or even abroad. Most of these young people are not equipped with adequate professional skills and can only find

\footnotetext{
*Corresponding author: Kamaruddinabd@gmail.com
} 
jobs as domestic helpers or taxi drivers. If this trend will continue, there is a consequence that only old peoples remain in the villages and have to take the responsibility to feed the nation with food enough to balance the ever increasing number of its population. Such burden to the old people is not supported with adequate equipment and technology, and hence their productivity is low and consequently import will become necessary.

Fortunately, villages in rural areas are blessed with abundant renewable energy sources such as solar, wind, hydro and biomass which may be converted into power and thermal energy. These energy sources in turn could then be used to power small industries such as Small Processing Center for value added activities in the villages. Such industries then can offer more job opportunities preventing its population from leaving the villages. In order to prove this postulate three hamlets have been chosen, one each in West Java, in Special Region of Jogjakarta and in West Nusa Tenggara, Indonesia [1-5].

Survey to these hamlets then were conducted to collect data on the availability of renewable energy sources as well as leading economic sectors determined by construction of each I/O Tables for the chosen hamlet $[6,7]$. Appropriate renewable energy technologies then were selected to supply energy for the leading economic sector [8-13]. Later cash flow analysis were conducted to determine economic viability of the system recommended and adjusted using PEST analysis. The PEST analysis will be used to determine the proper policy on electricity tariff to be imposed, the economic aspect regarding the interest rate of loan, social awareness on number of people involve in the business venture and the technology being used in order to ensure sustainable development.

\section{Renewable energy sources at each hamlet}

Tangsi Jaya hamlet, located in West Bandung city, West Java, has been provided with a $18 \mathrm{~kW}$ micro-hydro power plant (Figure 1) and is utilized to supply electricity both to the community as well as to Small Processing Center (SPC) for ground coffee production which was found to be the leading economic sector for the hamlet. The SPC has a processing capacity of $3266 \mathrm{~kg} \mathrm{mo} \mathrm{mo}^{-1}$ (Figure 2) [2].
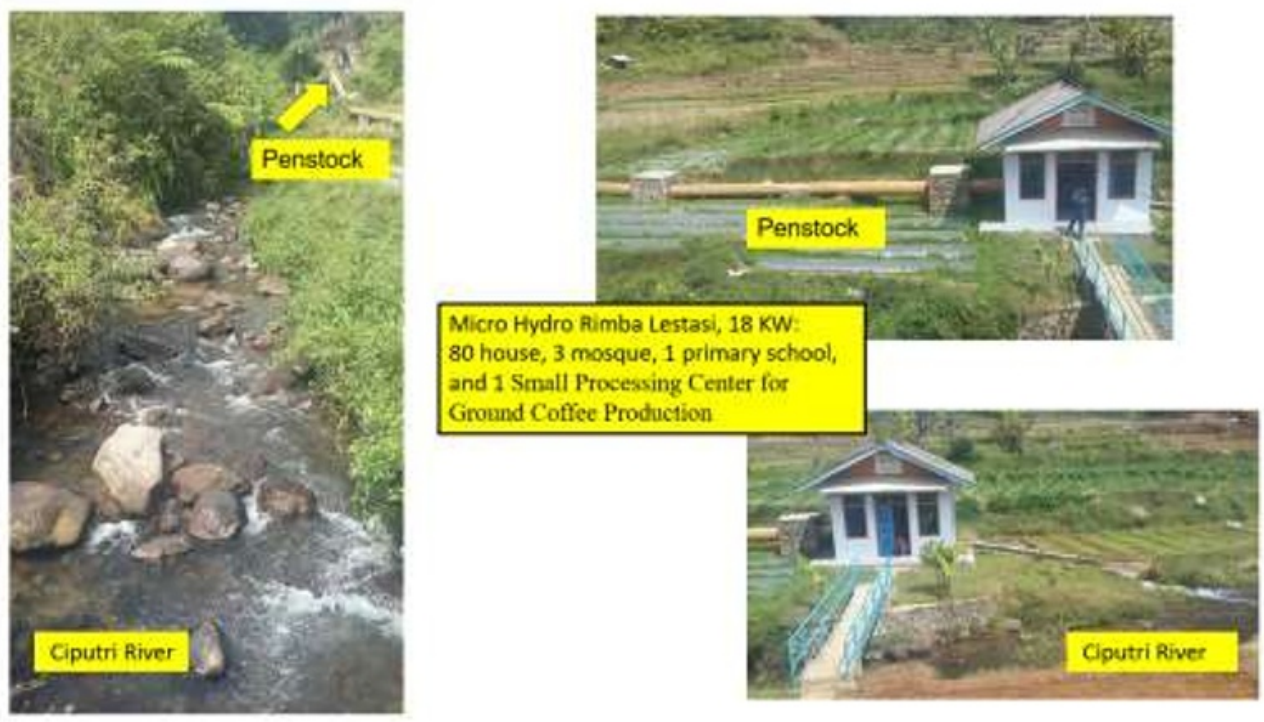

Fig1. Micro-Hydro Rimba Lestasi, $18 \mathrm{KW}$ in Tangsi Jaya, Bandung 

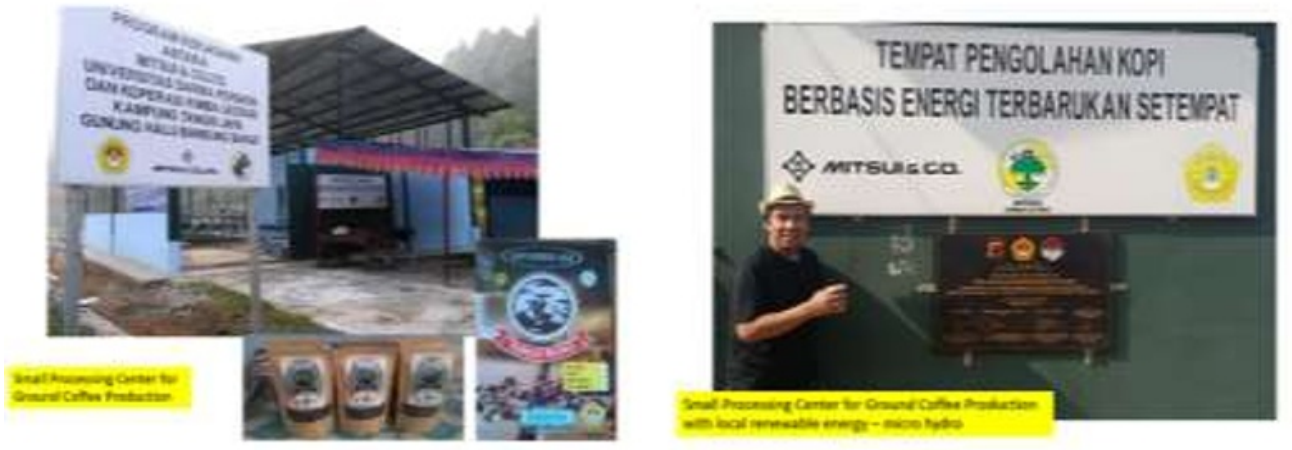

Fig.2. Small Processing Center for Ground Coffee Production with local renewable energy - microhydro in Tangsi Jaya, Bandung

Banyumeneng I hamlet, located in special region of Jogjakarta, has been provided with a $1200 \mathrm{~kW}$ solar water pumping system, to supply water to some 25 households (Figure 3). The hamlet has potential for solar energy with an average $4.8 \mathrm{kWh} \mathrm{m}^{-2} \mathrm{~d}^{-1}$ and wind of $3.3 \mathrm{~m} \mathrm{~s}^{-1}$ not to mention biomass wastes from the forest, and animal wastes. Here solar wind and biomass will be used to produce shredded tobaccos which was the leading economic sector for the hamlet. The processing capacity of the dryer was assumed to be $11335 \mathrm{~kg} \mathrm{yr}^{-1}[3]$
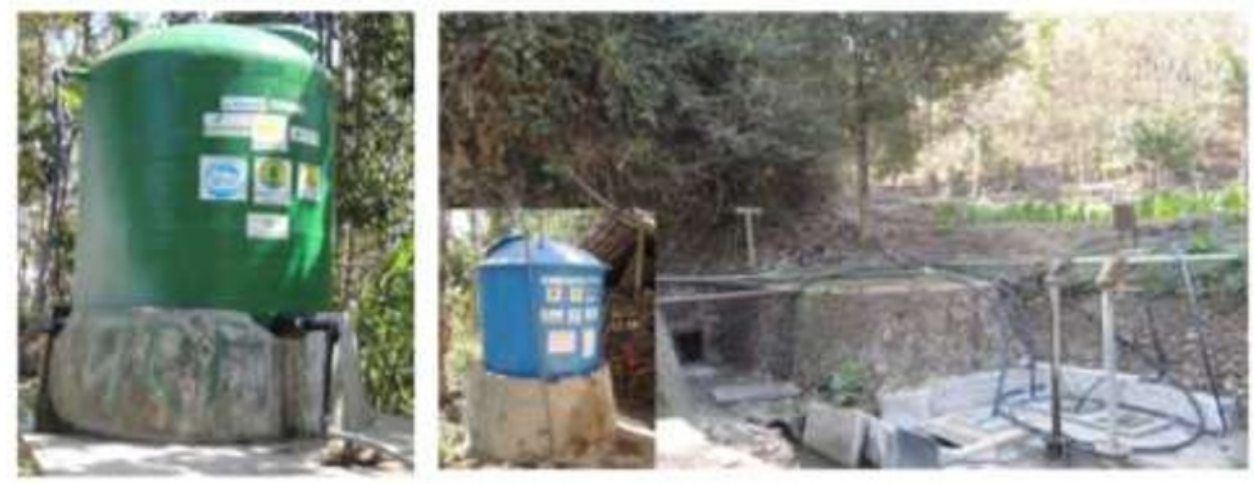

Fig.3. Solar water pumping system in Banyumeneng I hamlet, special region of Jogjakarta (source: kabarhandayani.com)

Seriwe hamlet, located in East Lombok regency, West Nusa Tenggara has potential in solar and wind with an average of $4.8 \mathrm{kWh} \mathrm{m}^{-2} \mathrm{~d}^{-1}$ to $5.1 \mathrm{kWh} \mathrm{m}^{-2} \mathrm{~d}^{-1}$ of solar and wind around $4.2 \mathrm{~m} \mathrm{~s}^{-1}$. Here a hybrid solar and wind has been proposed to dry seaweeds the leading economic sector (Figure 4). The processing capacity of the dryer was assumed to be $500 \mathrm{~kg} \mathrm{~d}^{-1}[4]$. 


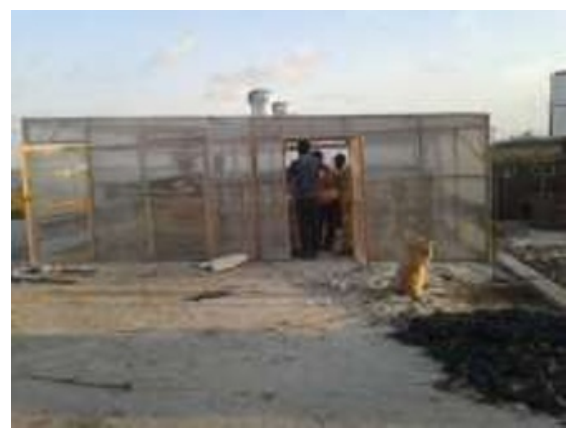

Fig. 4a. A hybrid solar-wind dryer for seaweeds in Seriwe hamlet

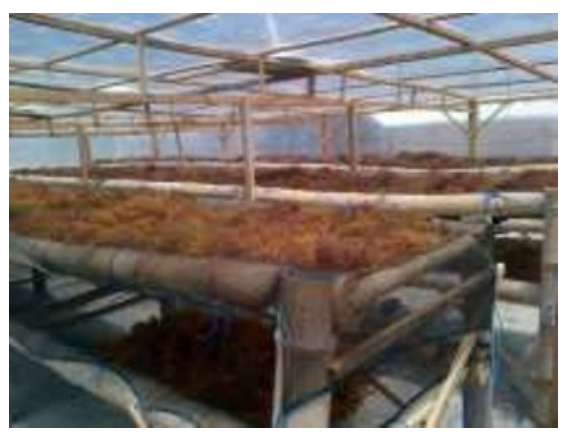

Fig. 4b. Seaweeds drying in Seriwe hamlet

\section{Cash flow analysis}

Results of cash flow analysis for ground coffee SPC in Tangsi Jaya hamlet indicated that the for the case of $50 \%$ Arabica coffee and $50 \%$ Robusta coffee production, with total investment of IDR 110750000 (USD 11417.5 ) and discount rate of $18 \% \mathrm{yr}^{-1}$ for $5 \mathrm{yr}$, the break-even point was estimated to be $2 \mathrm{yr}$ with NPV of IDR 316746276 (USD 32 654.2). Here the electricity tariff from the micro-hydro was set at IDR $139 \mathrm{kWh}^{-1}$ (USD $0.0143 \mathrm{kWh}^{-1}$ ) [2].

For the case of cash flow of tobacco shredder for Banyumeneng I hamlet, where a leasing system was used, with an investment cost IDR 95000000 (USD 9 793.8) and production cost of IDR $34195000 \mathrm{yr}^{-1}$ (USD 3 525.3) and the interest rate of $14 \% \mathrm{yr}^{-1}$, the payback period was estimated to be $3 \mathrm{yr}$ with ROI of $40 \%$. Here as auxiliary heating a biomass stove was used and electricity tariff of IDR $650 \mathrm{kWh}^{-1}$ (USD $0.067 \mathrm{kWh}^{-1}$ ) was applied. Results of cash flow analysis for an hybrid solar-wind-LPG dryer, the investment was IDR 21548000 (USD 2 221.4) in which the hybrid solar-wind-LPG dryer was considered as a grant, using the leasing system, the payback was achieved in $5 \mathrm{yr}$ for the case of discount rate of $14 \% \mathrm{yr}^{-1}$ and the ROI was $24.7 \%$. Here six blowers were used in the calculation to assist LPG heating [3].

\section{PEST analysis}

As mentioned previously there are four main barrier to the effective utilization of renewable energy technologies. There are namely, P, policy which can relate to electricity tariff, E. the economy which may relate to the discount rate, $\mathrm{S}$, social awareness, the number of people involve in the project, and $\mathrm{T}$, the applied renewable energy technology. The authors are required to determine what is the appropriate electricity tariff and discount rate for a specific case of a certain number of people involve in the SPC when a certain renewable energy technology is to be applied. In order to do this, it is necessary to formulate linkages among parameters such as in the following. If $\mathrm{Ci}$, is the $\mathrm{ROI}$ of the hybrid solar-wind and LPG, and coefficient $\mathrm{Ci}\left(\mathrm{a}_{\mathrm{i}}=1,2 \ldots 4\right)$ respectively $\mathrm{a}_{1}$ for $\mathrm{P}, \mathrm{a}_{2}$ for $\mathrm{E}, \mathrm{a}_{3}$ for $\mathrm{S}$ and $\mathrm{a}_{4}$ for $\mathrm{T}$, then the following relation may apply in Equation (1).

$$
C_{i}=a_{1} P+a_{2} E+a_{3} S+a_{4} T
$$


Table 1. An excersise for the condition in Seriwe hamlet*).

\begin{tabular}{|c|c|c|c|c|c|}
\hline $\begin{array}{c}\text { Policy } \\
\text { (electricity tariff } \\
\text { IDR } \mathrm{kWh}^{-1} \text { ) } \\
\end{array}$ & $\begin{array}{c}\text { Economy } \\
(\text { Discount rate- } \\
\left.\% \text { annum }^{-1}\right)\end{array}$ & $\begin{array}{c}\text { Social awareness } \\
\text { (number of people } \\
\text { involve) }\end{array}$ & $\begin{array}{l}\text { Technology } \\
\left(\operatorname{IDR} 10^{6}\right)\end{array}$ & ROI & $\begin{array}{c}\text { Calculated } \\
\text { ROI }\end{array}$ \\
\hline 960 & 14 & 20 & 60 & 0.247 & 0.264 \\
\hline 610 & 16 & 40 & 120 & 0.81 & 0.827 \\
\hline 1800 & 15 & 60 & 180 & 1.22 & 1.278 \\
\hline 720 & 13 & 20 & 60 & 0.262 & 0.302 \\
\hline 810 & 12 & 40 & 120 & 0.832 & 0.863 \\
\hline 1000 & 14 & 60 & 60 & 0.246 & 0.448 \\
\hline
\end{tabular}

*) USD 1 = IDR 9700.

From the Table 1, each coefficient were ditermined by means of Least Square Method and was found to be as the following.

$\mathrm{a}_{1}=-0.001, \mathrm{a}_{2}=-0.014, \mathrm{a}_{3}=0.0047$ and $\mathrm{a}_{4}=0.077$

which indicate that the higher electricity tariff and interest rate while the higher the value of technology and number of people involve with the SPC will result in the bigger value of ROI. From this coefficient one can determine the proper tariff and interest rate for the SPC $[10,11]$.

\section{Development - Waste Utilization}

Renewable energy can create small industries in rural areas, with a positive impact on sustainable economic development. However, vigilance is needed because small industries can also cause pollution because they produce waste. Several literatures has stated that industrial waste from coffee processing, tobacco processing, and seaweeds drying and processing has the potential to have negative impacts on river water, soil and air.

The use of waste to generate energy is reported in these manuscripts, to support energy security in rural areas. Reference $[14,15]$ describes the use of agricultural waste into smallscale biogas. In particular, $[16,17]$ reported biogas from seaweeds waste. Yi Liu et al. [18] stated the success of biogas from tobacco waste. Palupi et al. [19] suggested tobacco waste to be bioethanol. Solid waste, i.e. husks from coffee processing, was presented [20] as biobriquettes. Harsono et al. [21, 22] reported the successful fermentation of husks into bioethanol in Ijen coffee plantation, Jember, Indonesia.

Setyobudi et al. [23] has analyzed the characteristics of coffee pulps and stated its feasibility as a biogas feedstock. However, because the pulps are buoyant and the $\mathrm{pH}$ tends to be acidic, a two-stage digester is recommended [24, 25]. Especially in 1st digester, it is recommended to use ballast [23, 26, 27].

Coffee processing solid waste (pulps and husks) further increases the added value when processed as additional food ingredients. Setyobudi et al. [28], Mindarti, et al. [29] suggested that coffee husks and pulps be transformed into functional food, namely coffee cherry flour (CCF). Damat et al. [30] stated that CCF has a positive impact because it increases the dietary fiber and antioxidant activity in cookies made from gluten-free ingredients. 


\section{Conclusion}

It has been demonstrated how renewable energy technology could be used for value added activities in rural areas, create small industries, provide job opportunities to the local people and create conditions for sustainable economic development. Thus, it can also create a better civilization and increase the per capita income of the community. However, vigilance is needed because small industries can also cause pollution because they produce waste.

The authors would like to thank Mitsui \& Co, Japan, who assisted in the research project in Tangsi Jaya, West Bandung and Seriwe West Nusa Tenggara. The authors also thanks to the Student Community Center for Energy (Kamase), Department of Engineering Physics, Universitas Gajah Mada, Yogyakarta, for their cooperation in a UNESCO-funded research project in the hamlet area, Banyumeneng 1, Giriharjo Village, Panggang, Yogyakarta Special Region.

\section{References}

1. Darma Persada University and Gadjah Mada University, Application of Leap for the Development of Tangsi Jaya Village, G. Halu and Banyumeneng Village, G. Kidul as the E3i Village Model. Unesco Jakarta: Project Final Report (2012). [Online unpublished].

2. A. S. Uyun, A. Kamaruddin, Konsep perancangan energi di dusun Tangsi JayaGunung Halu, Bandung Barat sebagai model desa mandiri energi [The energy design concept in Tangsi Jaya-Gunung Halu hamlet, West Bandung is a model for an energy independent village]. Seminar hasil penelitian semester ganjil 2011/2012. I.N. Djajadiningrat, (Ed.). Jakarta: Lembaga Penelitian, Pemberdayaan Masyarakat dan Kemitraan, Universitas Darma Persada Jakarta (2012). p. 1-12. [in Bahasa Indonesia]. http://lp2mk.unsada.ac.id/wp-content/uploads/2016/04/PROSIDING-GJL-11-12.pdf

3. N.S. Wahyuni, S. Wulandari, E. Wulandari, D. S. Pamuji, Energy Procedia, 79:10271032(2015). https://www.sciencedirect.com/science/article/pii/S187661021502336X

4. A. Kamaruddin, A.S. Uyun, H.N. Rahman, E.Suherman, SY. Lumbessi, Using renewable energy to process seaweed, Mediterranean Green Buildings \& Renewable Energy, A. Sayigh (Eds), Cham: Springer (2017). p. 835-843. https://link.springer.com/chapter/10.1007\%2F978-3-319-30746-6_65

5. Darma Persada University, Development of Proper Economic Modeling for Improving the Indonesian Energy Strategy in Selected Indonesian Villages, A SEADI (Support for Economic Analysis Development in Indonesia)--USAID Project (2013). [Online unpublished].

6. A.F. Zobaa, R.C. Bansal, Handbook of renewable energy technology. Singapore: World Scientific (2011). https://www.google.com/books?hl=id\&lr=\&id=jWtYPbnJQVcC\&oi

7. I.H. Saizarbitoria, I. Zamanillo, I. Laskurain, Renewable and Sustainable Energy Reviews, 27:515-524(2013). https://doi.org/10.1016/j.rser.2013.07.032

8. H. Susanto, R.H. Setyobudi, Y. Chan, S.M. Nur, E. Yandri, J. Burlakovs, et al., IOP Conf. Series: Earth and Environmental Science, 490:012009(2020). https://iopscience.iop.org/article/10.1088/1755-1315/490/1/012009/pdf

9. N. Singh, R. Nyuur, B. Richmond, Sustainability 2019, 11(8), 2418(2019) https://www.mdpi.com/2071-1050/11/8/2418

10. T.D.H. Jury, Cash flow analysis and forecasting: The definitive guide to understanding and using published cash flow data (Vol. 653). USA: John Wiley \& Sons (2012). https://onlinelibrary.wiley.com/doi/book/10.1002/9781118467268 
11. A. Winata, N.D. Sunengsih, Widiastuti, E-Journal WIDYA Non-Eksakta, 1,1:5662(2018). [in Bahasa Indonesia].

https://e-journal.jurwidyakop3.com/index.php/ejournal-noneksakta/article/view/325

12. H. Susanto, K. Abdullah, A.S. Uyun, S.M. Nur, T.M.I. Mahlia, MATEC Web of Conferences 164(01012):1-17(2018).

https://www.matecconferences.org/articles/matecconf/abs/2018/23/matecconf_icesti2018_01012/matecc onf icesti2018_01012.html

13. I. Rosaira, W. Hermawati, Dampak listrik PLTMH terhadap kehidupan sosial ekonomi masyarakat di Dusun Gunung Sawur, Desa Sumber Rejo, Candipuro, Lumajang [The impact of PLTMH electricity on the socio-economic life of the community in Gunung Sawur Hamlet, Sumber Rejo Village, Candipuro, Lumajang]. Prosiding Konferensi dan Seminar Nasional Teknologi Tepat Guna, (Pusat Penelitian Perkembangan Iptek LIPI, 2014), p. 456-507. [in Bahasa Indonesia]. https://repository.ipb.ac.id/jspui/bitstream/123456789/82502/3/6. PROSIDING-MPemasyarakatan_TTG-1.pdf

14. N.I.H.A. Aziz, M.M. Hanafiah, M.Y.M. Ali. Renew. Energy, 132:363-369(2019). https://doi.org/10.1016/j.renene.2018.07.149

15. R. Kapoor, P. Ghosh, M. Kumar, S. Sengupta, A. Gupta, S.S. Kumar, et al., Bioresour. Technol, 04:123036(2020). https://doi.org/10.1016/j.biortech.2020.123036

16. M. Kawaroe, S. Dohong, D.F. Lestari, World Appl. Sci. J., 35,5:661-668(2017). https://doi.org/10.5829/idosi.wasj.2017.661.668

17. S. Tedesco, S. Daniels. Appl Energy, 228:712-723(2018). https://www.sciencedirect.com/science/article/abs/pii/S0306261918309899

18. Y. Liu, J. Dong, G. Liu, H. Yang, W. Liu, L. Wang et al., Bioresource Technology 189:210-216 (2015). http://dx.doi.org/10.1016/j.biortech.2015.04.003

19. B. Palupi, B.A. Fachri, I. Rahmawati, A. Susanti, F.A. Setiawan, P.G. Adinurani, et al., Ann. Trop. Med. PH., 23,8:1213-1219(2020). https://www.journal.atmphspecialissues.org/uploads/179/7615_pdf.pdf

20. S.S. Harsono, R. Dila, M. Mel, J. Environ. Sci. Curr. Res. 2:004(2019). http://www.heraldopenaccess.us/openaccess/coffee-husk-biopellet-characteristics-assolid-fuel-for-combustion-stove

21. S.S. Harsono, Salahuddin, M. Fauzi, G.S. Purwono, D. Soemarno, Kissinger. Procedia Chem., 14:408-413(2015).

https://www.sciencedirect.com/science/article/pii/S187661961500056X

22. S.S. Harsono, M. Fauzi, Internat. J. of Trop. Nat. Sci. 1,2:17-21(2015). http://repository.unej.ac.id/bitstream/handle/123456789/79699/9\%20Mularmarwan\%2 0-\%20Samarinda\%202.pdf? sequence $=1 \&$ is Allowed $=y$

23. R.H. Setyobudi, S.K. Wahono, P.G. Adinurani, A. Wahyudi, W. Widodo, M. Mel, et al., MATEC Web of Conference. 164,01039:1-13(2018).

https://doi.org/10.1051/matecconf/201816401039

24. P.G. Adinurani, R.H. Setyobudi, S.K. Wahono, A. Sasmitod, L.O. Nelwan, A.

Nindita, et al., Int. J. Renew. Energy Dev., 3,1:73-78(2014).

https://doi.org/10.14710/ijred.3.1.73-78

25. R. Hendroko, A. Wahyudi, S.K. Wahono, P.G. Adinurani, Salafudin, D. Salundik, et al. International Journal of Technology 4,3:202-208(2013). https://ijtech.eng.ui.ac.id/old/index.php/journal/article/view/115

26. P.G. Adinurani, R.H. Setyobudi, S.K. Wahono, M. Mel, A. Nindita, E. Purbajanti, et al., Proc. Pakistan Acad. Sc 54,1:47-57(2017). http://www.paspk.org/wpcontent/uploads/2017/03/Proceedings-B.-Life-Sciences-541-March-2017.pdf 
27. R. Hendroko, T. Liwang, P.G. Adinurani, L.O. Nelwan, Y. Sakri, S.K. Wahono, Energy Proc., 32,47-54(2013).https://doi.org/10.1016/j.egypro.2013.05.007

28. R.H. Setyobudi, L. Zalizar, S.K. Wahono, W. Widodo, A. Wahyudi, M. Mel, et al., IOP Conference Series: Earth and Environmental Science. 293,012035:1-25(2019). https://doi.org/10.1088/1755-1315/293/1/012035

29. S. Mindarti, L. Zalizar, Damat, E.A. Saati, S. Fajriani. IOP Conf. Series: Earth and Environmental Science 462:012017(2020).

https://iopscience.iop.org/article/10.1088/1755-1315/462/1/012017

30. D. Damat, R. Anggriani, R.H. Setyobudi, P. Soni, Coffee Science. 14,4:493-500 (2019). https://doi.org/10.25186/cs.v14i4.1625 